\title{
Context and dating of newly discovered Aurignacian rock art from Abri Castanet (Dordogne, France)
}

Romain Mensan, Raphaëlle Bourrillon, Catherine Cretin, Randall White, Philippe Gardère, Laurent Chiotti, Matthew Sisk, Amy Clark, Thomas Higham and Élise Tartar

\section{OpenEdition}

1 Journals

Electronic version

URL: http://journals.openedition.org/paleo/2480

DOI: $10.4000 /$ paleo.2480

ISSN: $2101-0420$

Publisher

SAMRA

\section{Printed version}

Date of publication: 15 December 2012

Number of pages: 171-188

ISSN: $1145-3370$

\section{Electronic reference}

Romain Mensan, Raphaëlle Bourrillon, Catherine Cretin, Randall White, Philippe Gardère, Laurent Chiotti, Matthew Sisk, Amy Clark, Thomas Higham and Élise Tartar, « Context and dating of newly discovered Aurignacian rock art from Abri Castanet (Dordogne, France) », PALEO [Online], 23 | 2012 Online since 19 July 2013, connection on 24 July 2020. URL : http://journals.openedition.org/paleo/ 2480 ; DOI : https://doi.org/10.4000/paleo.2480

This text was automatically generated on 24 July 2020 .

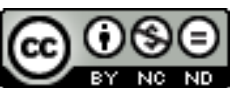

PALEO est mis à disposition selon les termes de la licence Creative Commons Attribution - Pas d'Utilisation Commerciale - Pas de Modification 4.0 International. 


\section{Context and dating of newly discovered Aurignacian rock art from Abri Castanet (Dordogne, France)}

Romain Mensan, Raphaëlle Bourrillon, Catherine Cretin, Randall White, Philippe Gardère, Laurent Chiotti, Matthew Sisk, Amy Clark, Thomas Higham and Élise Tartar

\section{1 - Introduction}

1 This paper presents the exceptional discovery of a fragment of a ceiling block bearing graphic imagery at the early Aurignacian site of Abri Castanet (Sergeac commune, Dordogne) in July 2007. Since the discovery, a multi-disciplinary team has studied the block and its context, not just within the Castanet infilling, but also within the context of the Castel-Merle valley. The aim of this study is to set this early modern human graphic representation in the context of all the daily and other human activities carried out at the site.

2 After a general presentation of the archaeological issues relevant to the period and the site, we present the initial objectives of this study, as well as the exact circumstances of the discovery of the block and the chosen extraction method.

3 We then undertake a description of the block itself, the study techniques used and the graphic entities represented.

4 Lastly, we present a multidisciplinary reflection linking this discovery to other archaeological and environmental data. 


\section{2 - Historic and discovery context}

5 Abri Castanet is one of the many rockshelter sites in the Castel-Merle valley, in Sergeac, opening out on the left bank of the Vézère, between Les Eyzies and Montignac (fig. 1). The site was discovered in 1911 by M. Castanet on the east slope of the valley while he was working on the excavation of Abri Blanchard, further north, for L. Didon (White et al. 2012). Excavations were then conducted by M. Castanet under D. Peyrony's supervision from 1911 to 1913, then in 1924-1925.

Figure 1 - Geographic situation of Abri Castanet in the Vallon des Roches at Sergeac (Dordogne, France), in red, the main Aurignacian sites in the Vézère and Dordogne valleys.

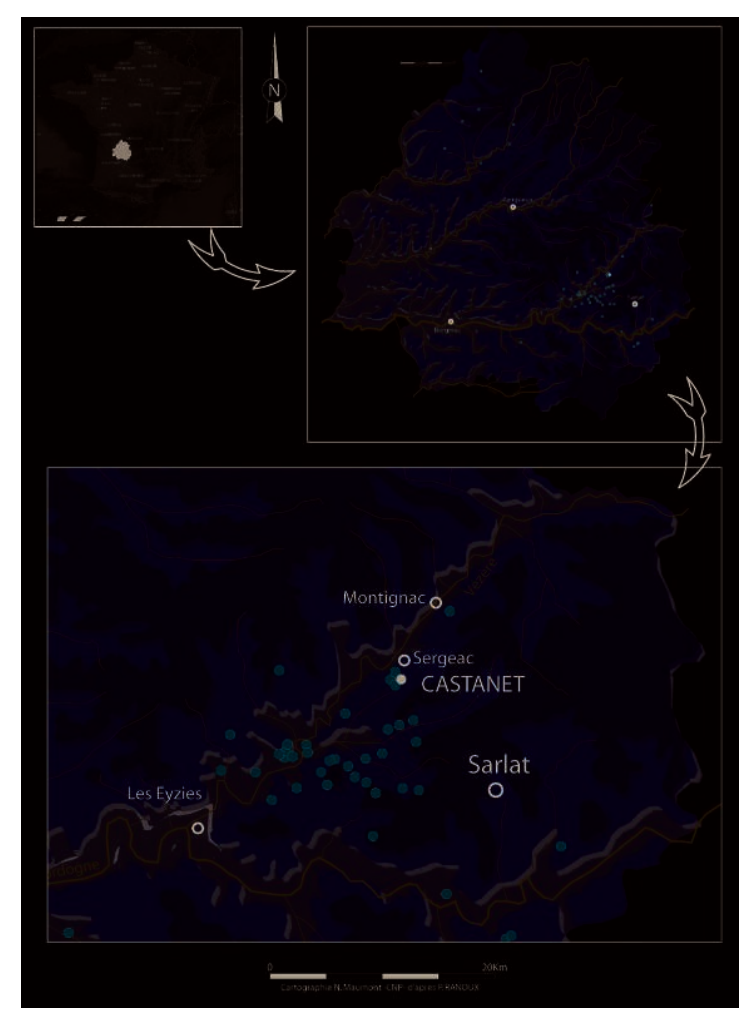

C. Cretin and N. Maumont, Centre National de Préhistoire, map collection @ Ministère de la Culture et de la Communication.

\section{The early excavations}

6 The site is a collapsed west-facing rockshelter which yielded a rich assemblage attributed to two archaeological levels, both of which are assignable to the Aurignacian (fig. 2). D. Peyrony only published the Abri Castanet results in 1935 (Peyrony 1935). He distinguished a lower level lying directly on the limestone bedrock and a very poor upper level, separated from the preceding by a sterile layer. The complex was covered by blocks from the collapse of the rock shelter. The lower level is attributed to the early Aurignacian (Aurignacian I) due to the presence of abundant cervid antler points with split bases, and the upper level to the recent Aurignacian (Aurignacian II) on the basis of the presence of two bone points with massive bases. However the lithic industry from both levels appears to be identical, as shown by D. de Sonneville-Bordes' 1960 study of the Peyrony assemblages (Sonneville-Bordes 1960). 
Figure 2 - Abris Castanet and Blanchard (Sergeac, Dordogne, France), artefacts representative of the Aurignacian culture. 1: Bone Industry; 2: Lithic Industry; 3: Ornaments; 4: Rock Art.

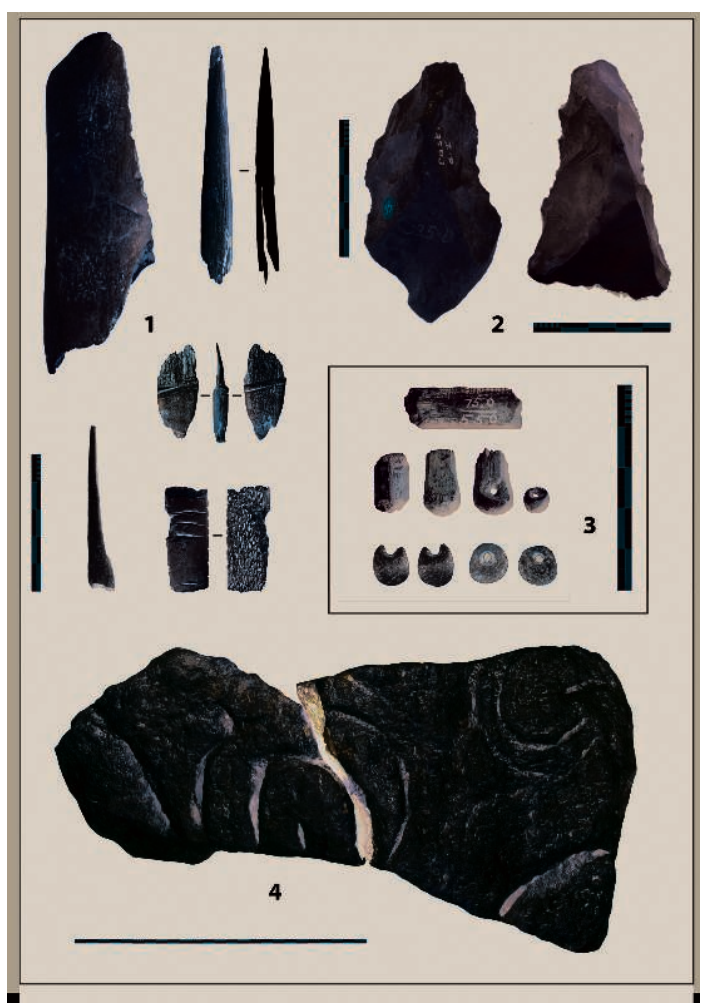

É. Tartar, L. Chiotti, R. White, C. Cretin and R. Bourrillon. Photo of the engraved block by Ph. Jugie (c)MNP Les Eyzies - Dist. RMN.

7 As for Abri Blanchard, Abri Castanet contains abundant ornamental elements (White 2008b), bone industry (Tartar 2007, 2009), but also anthropic modifications on limestone blocks (wall art, block art, fashioned anneaux or rings...). Although M. Castanet attributed the engraved or painted elements to specific levels, none of them has a real archaeological context. Most of them were found after the excavation among blocks put aside for examination and washing.

8 Although many Aurignacian sites have been excavated over the past forty years in the southwest of France (La Ferrassie, Le Flageolet, Les Rois, Brassempouy, Abri Pataud, Le Piage, etc. $)^{1}$, none appears to be comparable to the Castanet - Blanchard complex, especially as far as the rock art is concerned. The evolution of theoretical questions and archaeological methods thus provided the basis for a renewed excavation project at Abri Castanet.

\section{Recent excavations}

9 An evaluation survey thus began in 1994, directed by J. Pelegrin and R. White (Pelegrin \& White 1998). The main objectives were to identify the location of the D. Peyrony and M. Castanet excavation in order to look for possible deposits in primary position under the spoil, to clean a sagittal section visible in the talus and, lastly, to evaluate the remaining archaeological potential further to the south. 

and have not revealed any in situ level. The cleaning of the sagittal section brought to light the Aurignacian level in contact with the limestone bedrock. Several testpits in the talus south of the Peyrony sector confirmed the presence of this same level about ten meters to the south of the section left by D. Peyrony. An excavation operation was thus carried out from 1995 to 1998, in the sector currently known as the "south sector". These first modern excavations in the Roches valley have revealed a relatively straightforward stratigraphy:

- a base archaeological level lying directly on the bedrock;

- collapse of the front of the shelter;

- sealing off by sediments from the plateau

Prehistoric groups were thus installed directly on the limestone bedrock of the rockshelter under a porch. They occupied a surface several meters wide before the collapse of the porch sealed the anthropic deposits. A thick layer of sediment settled on this scree, forming a wide cone against the rockshelter wall. The 1994 to 1998 operations contributed to a good understanding of the rockshelter infilling and brought to light the pre and post-depositional phenomena which affected the infilling.

It is important to point out that doubts were raised as regards the upper level, attributed to the recent Aurigancian by D. Peyrony (Aurignacian II), during this first diagnostic, as no layer posterior to the layer in contact with the bedrock was identified.

\section{Context of the discovery}

Investigations in the south sector of the rockshelter were renewed in 2005 (White 2005, 2006, 2007a, 2008a, 2009a; White et al. 2010). The aims were to document the Aurignacian level over a larger surface and to anchor it in a geomorphological context (Mensan 2007; Mensan \& Sisk 2008). In order to do this a multidisciplinary study was conducted in the valley to combine historiographic, geological, geomorphological, topographic and archaeological data on the occupations of the east slope of the Roches valley.

This new approach enabled us to pursue the excavation of the south sector of the rockshelter and to include the north sector, referred to as the "Peyrony sector", in our project. The stratigraphic sections drawn in 2006 show that this level lies directly on the bedrock, just like in the south sector. This level, characterized by abundant archaeological objects and a purple color, was already identified in 1994 and was called the "purple layer". The sagittal section left by Peyrony is an appropriate window for the long distance observation of the characterization of lateral variations of the facies of an archaeological level.

The north sector presents a globally identical stratigraphy to that observed in the south sector. However, unlike the south sector where only the rear part of the infilling has been preserved, the Peyrony sector represents the front part of this infilling. In the south, this front zone was destroyed during road building in the 1960s.

In the small studied observation window, the archaeological level was sealed by a block which seemed to come from the collapse of the rockshelter porch, and which was overlain by the upper fill levels. It was thus necessary to remove this block, embedded in the section left by Peyrony in 1925. The size of this block must have prevented it 
from being evacuated and part of it was cut off in the past, undoubtedly during the 1924-1925 excavations.

17 This section was recorded in 1995 (Texier 2009 - p. 105) and again in 2006 (White 2006) (fig.3), but it does not appear to be the section drawn by Peyrony which seems to be located several meters north of this one. This block, which we called "block K", was already visible during the 1994 operation but its exact volume remained unknown at the time as it was partly covered by the infill. A posteriori, it turns out to be $0.650 \mathrm{~m}^{3}$ and weighs over $1.5 \mathrm{t}$.

Figure 3 - On the left, D. Peyrony's stratigraphic section; on the right, the 2007 stratigraphic section.

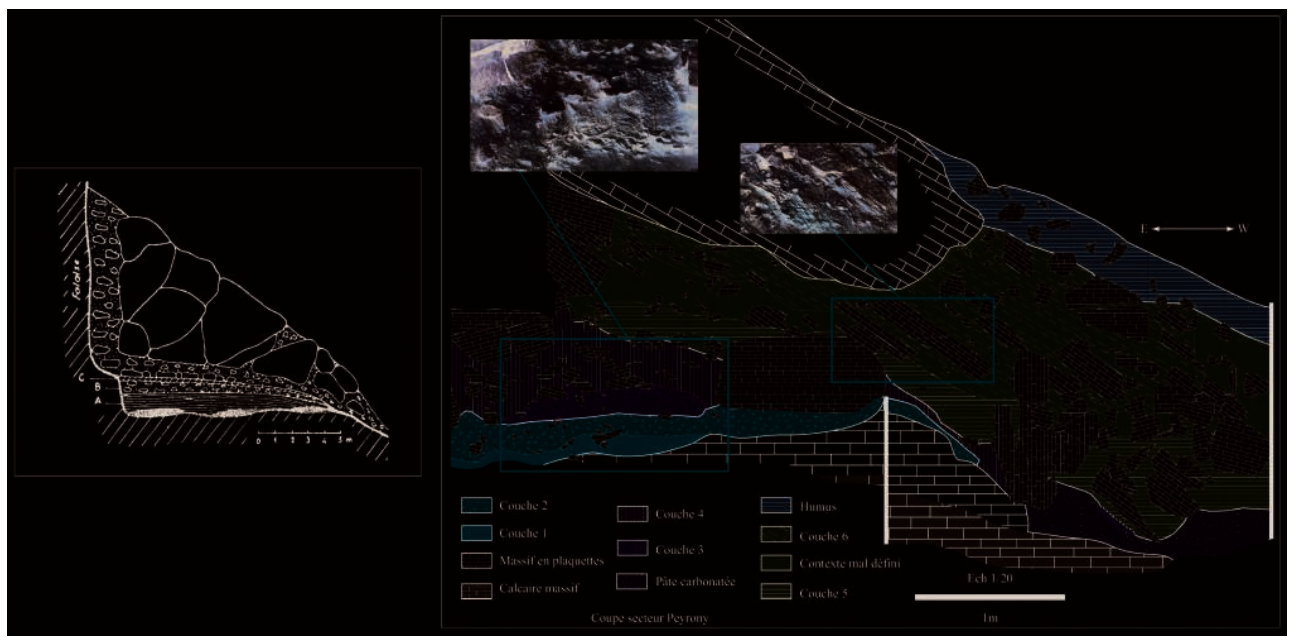

P. Gardère, R. Mensan and P. Kervinio.

The removal of block $\mathrm{K}$ and the discovery of the graphic elements: context, methods and restitution

\section{Extraction method}

The aim was to extract a block of unknown dimensions without disturbing the underlying archaeological level or the section, which was capped by an enormous block (White et al. 2007) (fig. 4). It was essential to preserve the underlying archaeological layer in order to characterize the lateral sedimentary variations of a level in the same stratigraphic position in the valley. The position of the remaining stratigraphic sequence, at the bottom of a narrow trench, on a talus more than $1.5 \mathrm{~m}$ high, ruled out the possibility of using mechanical leverage, which would, in any case have required the removal of the overlying rocky mass, causing the brutal gouging out of considerable quantities of sediments. This would have prevented the detailed study of the relationship between the block, the archaeological layer and the overlying fills (whether archaeological or not). 
Figure 4 - Top, Peyrony section with block K in place; Bottom, Peyrony section after the extraction of block $\mathrm{K}$.

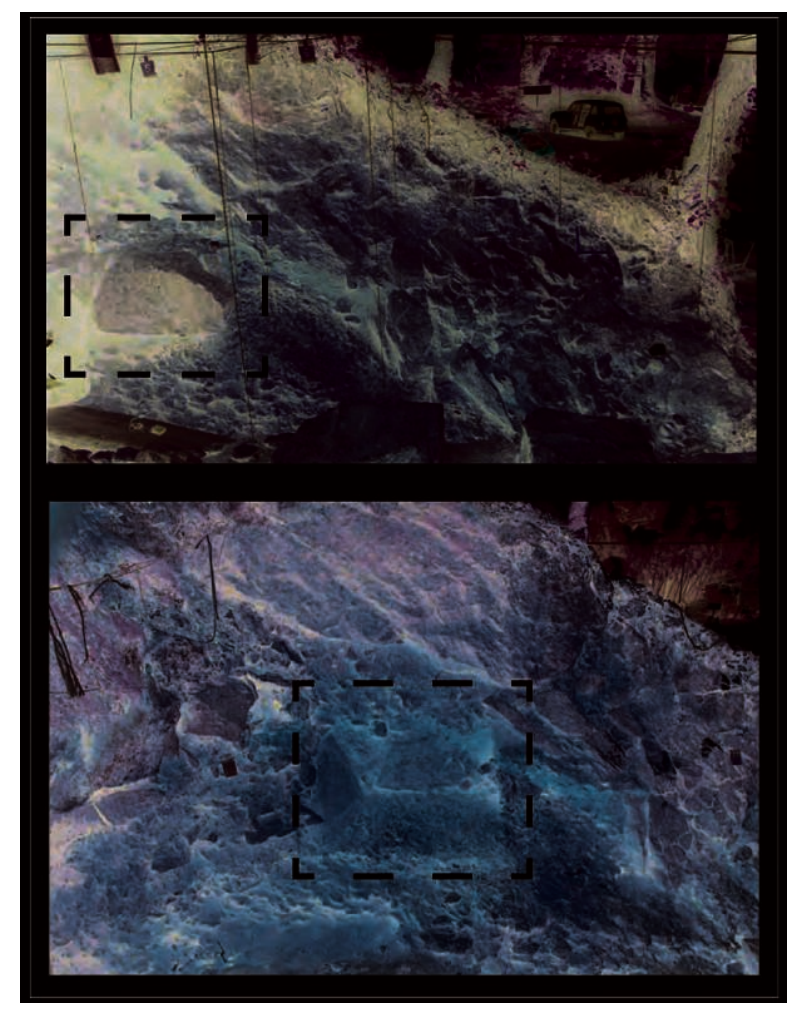

R. White and R. Mensan splitting wedges. The possibility of the presence of decorative elements on the block had been anticipated and the manual manipulation of the fragmented block appeared preferable to mechanical traction, as it would not be possible to check the block for decoration throughout the procedure with the latter option. The subdivision of the block was controlled throughout and the block was totally restituted afterwards. Moreover, the systematic photography of each stage of the operation turned out to be invaluable for the contextualization of the decorated block. A platform was erected over the trench in order to lift up the block fragments progressively, to check whether or not the underlying layer was adhering to the fragments, then to gently tip the blocks on their side, wedging them against sand bags to ensure their stability. The surfaces in contact with the archaeological levels were thus neither handled nor washed.

Between June 22 and July 9 2007, a total of twelve fragments were detached from block K. Seven of them (K1 to 7), bore part of the decorated surface in contact with the archaeological layer. Fifteen other blocks clearly belonging to the same original rocky mass and broken in situ, either when they fell or by compression, were also removed from this sector on July 12 and July 132007.

\section{Restitution of the block after subdivision}

21 It is important to bear in mind that the different fragments were numbered after the operation according to the observation of the decorated surface, that is, the underside 
of the block, when it was still in the rock shelter. There is thus a discontinuity between the chronology of field operations and the numerical sequence ${ }^{2}$ (fig. 5).

Figure 5 - Block K. Graphic rendering executed on 3D support with reassembly of all the fragments as a photomosaic; numbering of fragments and first attempt at refitting fragments (1-7) using 3D scanning.

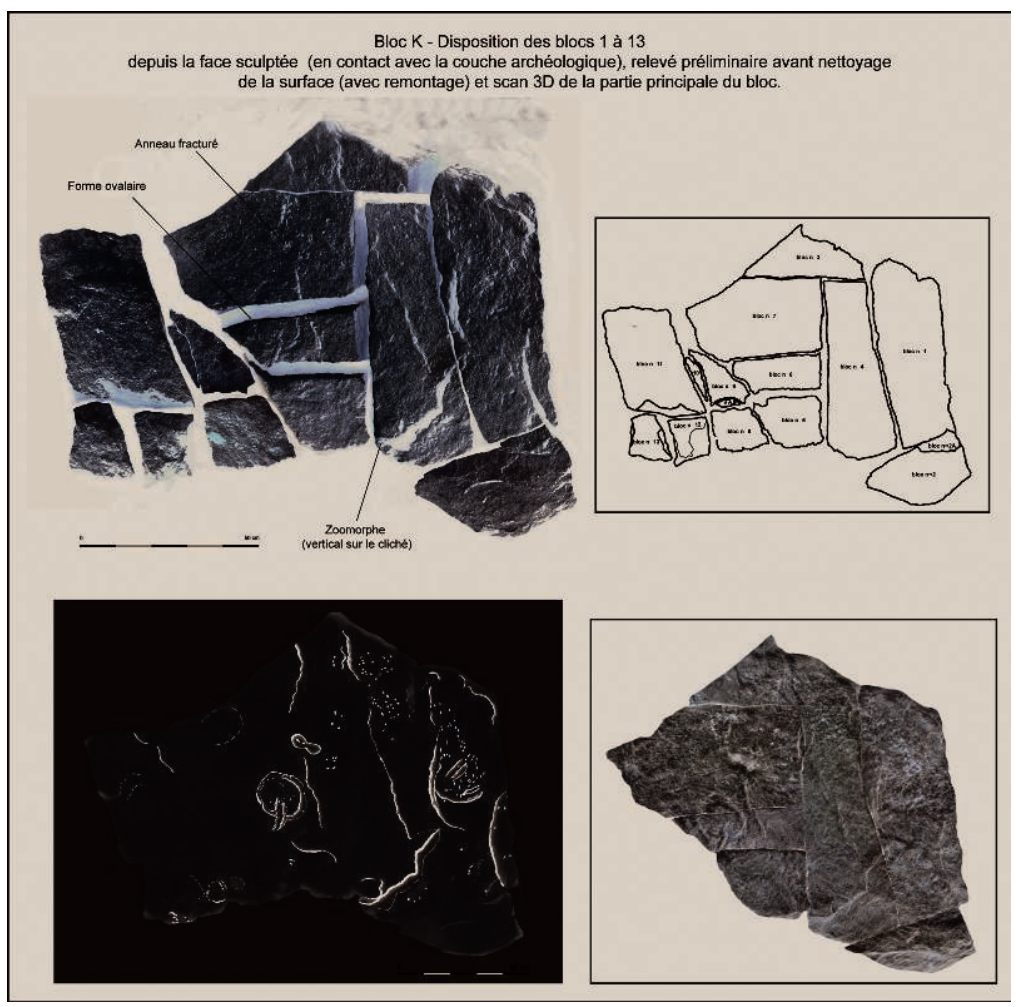

R. Bourrillon, C. Cretin and M. Sisk.

\section{3 - The graphic elements: first observations}

\section{Study techniques of the block}

In spite of all the precautions taken to preserve the underlying purple layer, the underside of the block was nonetheless covered with a fine layer of sediment (up to 1 $\mathrm{cm}$ thick), which made it impossible to accurately examine the surface, the technical marks and the graphic representations. In order to preserve the block, no cleaning was carried out after extraction (Bourrillon 2007; White, Bourrillon 2008). In this sediment, bone fragments and small flint flakes are still in contact with the decorated underside of the block. While waiting for the surface to be cleaned, we thus present here a preliminary description. The interpretative iconographic and technological proposals advanced here will therefore be confirmed or rebutted in the future.

In order to identify the possible presence of anthropic pigments and to measure the impact of a superficial surface cleaning, elementary analyses were conducted. $\mathrm{X}$ Fluorescence was carried out during the last fieldwork season in 2010, by J. de Sanoit and D. Chambellan from the CEA (Sanoit (de) et al. 2005). The first results of these analyses confirm color stability and we can thus envisage superficial cleaning of the 
decorated surface with a soft dry brush. It is important to point out that the composition of the red color on the block is not distinguishable from that of the "purple layer" and could correspond to contamination by the archaeological level.

The preliminary mapping of block $\mathrm{K}$ was conducted with photographic survey techniques (Lorblanchet 1995; Fritz \& Tosello 2007) (cf. fig. 5). This method meets all conservation requirements for decorated surfaces and is extremely true to the original. The technique is made up of four stages:

1. High definition digital photography of the whole surface (respecting the same distances and angles) with lighting of varying incidence (natural light and artificial lighting);

2. The images are then rendered using computer graphics to improve readability or contrast. A photomosaic of the block was composed from 10 pictures;

3. The data visible on the photos is then traced on a transparent film;

4. The ultimate stage consists in finalizing the images which are scanned and processed by computer graphics.

Since this first study carried out in 2007, we chose to apply two new mapping methods. One of them entails taking topographic readings coupled with Gigapan recording ${ }^{3}$ and the other uses a 3D scanner ${ }^{4}$ at close range (Minolta VI $910^{5}$ ). Each of these methods aims to improve the mapping and the reading of shaping marks and also to facilitate the virtual manipulation and the conservation of voluminous items. Moreover, they contribute to the high resolution documentation of the block and thus help to monitor the evolution of the state of the surface.

\section{Visible graphic features and technical execution}

The entire engraved surface of the block appears to have been worked, as suggested by the presence of technical marks (hammering, pecking - Beaune (de) 1993; Delluc \& Delluc 1978), but this remains to be confirmed after cleaning (cf. fig. 5). In spite of the presence of sediments on the surface, as well as a fine carbonated layer which impairs visibility, three graphic elements are recognizable: a zoomorphic figure, an ovoid shape and two wide cup marks.

Deeply scored zones and higher zones alternate over the surface of block K. One end is deeply scored, whereas in the center of the block, a zoomorphic shape was outlined in bas-relief. Another bas-relief outline is visible at the other end of the block, accentuating the different heights.

merphic figure is in slight bas-relief and the mesial part is deeply chiseled (cf. fig. 5). The shaped status of the bas-relief part remains to be confirmed. This figure is made up of forequarters with an elevated coil, a pointed front leg and a ventral line. The rest of the figure is not easy to decipher and may never have been represented. It could correspond to a schematic bovid outline.

Two aligned cup marks with very clear chisel scars are located on the upper part of the fragment (cf. fig. 5). These two cup marks may be related to the presence of a ring although the absence of bridging fractures casts doubt on this interpretation. Moreover, the presence of chisel scars (probably using perpendicular percussion judging by the impact shapes) between the two cup marks is not generally observed for Aurignacian rings. However, it could be a broken ring with subsequently reworked fracture planes. 

and deep (around $0.5 \mathrm{~cm}$ ) worked outlines (fig. 6). This was the first engraving to be identified when the block was extracted. The outline is pitted, with regularization of the line. At the base, the outline is indented or "invaginated", following the terms used by B. and G. Delluc (Delluc \& Delluc 1978). The interpretation of this figure is still open to discussion. The most obvious interpretation is that of oval-shaped female genitals. However the figure is difficult to interpret because of a strongly underscored curved line at the base. This could represent a vulval opening but the volume used casts doubt on this interpretation. A last, more debatable suggestion would be that it illustrates a male sexual organ, which is a known theme during these early Aurignacian phases (Delluc \& Delluc 1978; Bourrillon 2009a,b).

Figure 6 - Block K, the ovoid form and close-up of pecking traces.

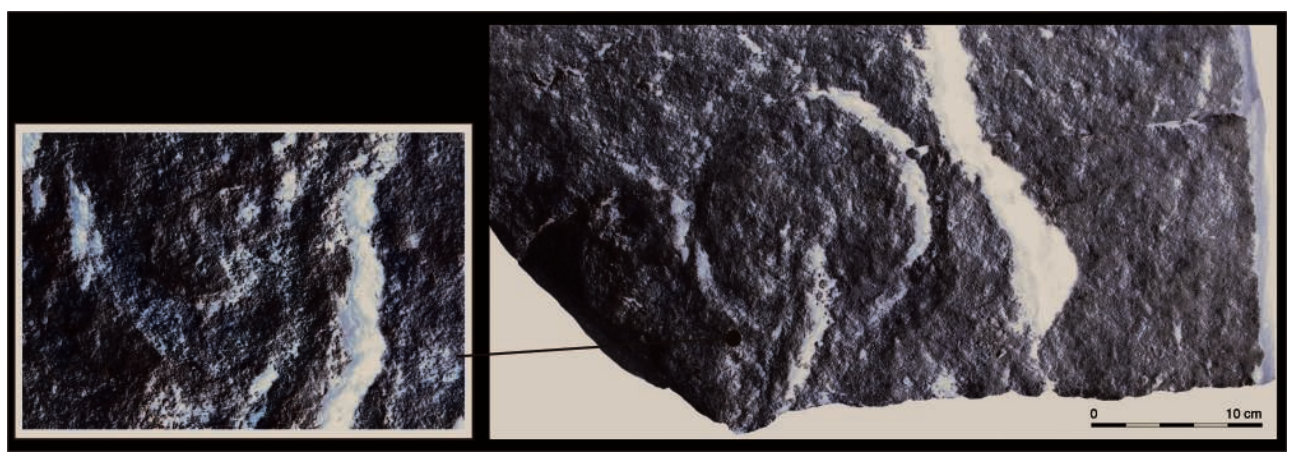

R. Bourrillon.

The techniques used are traditional for the Aurignacian period in the region. Hammering marks are identifiable over a large part of the block surface suggesting preparation prior to engraving (cf. fig. 5). Chiseling was used for the graphic features and outlines were regularized by scraping and abrasion (to be confirmed). This is illustrated by a more or less regular outline with cup mark remnants on the edges (cf. fig. 6).

Another observed technical feature is highlighting the elevation of part of the rock surface. This is the reserve relief technique ${ }^{6}$, suggested by the shaping marks on the peripheral part of the rear end of the zoomorphic figure.

In order to gain a better understanding of the chaîne opératoire used for the graphic rock art representations and of the techniques used, we have programmed experiments on limestone surfaces. This will enable us to address the question of the functional relationship between the parietal art and the material remains (tools and waste products) used to produce it.

The themes and techniques identified here concur perfectly with those already identified for this Aurignacian period in the Périgord region (Delluc \& Delluc 1978; Bourrillon, White 2007; White et al. 2012). But the most important aspect is the discovery of a decorated ceiling fragment in context which prompts us to revise our reading (graphic and technological) of decorated blocks but also to examine their distribution in the site using available archives. The sites of Castanet and Blanchard present many similarities and will thus be studied conjointly as part of this new research. It appears essential to closely study the context of these blocks and to clarify precisely when the decoration took place (on walls/ceilings or on the ground) in order 
to understand the role of these practices. This research is ongoing and is currently carried out as part of the Fyssen Foundation Grant program.

\section{4 - Contextualization}

\section{The archaeological layer}

The controlled removal of block $\mathrm{K}$ enabled us to preserve the archaeological layer and to observe its morphology and composition.

The fragments of the block clearly left their imprint on the archaeological level: at least two of the engravings identified during mapping left an imprint on the sediment. Under the block, the level presents color and texture variations: a yellow colored surface dominated by limestone plates with fragmented material as well as a strip of a purple layer in the northwest angle were identified. This is layer A, excavated by D. Peyrony and M. Castanet, which must have spread out to the north of the section where it contained a dense concentration of archaeological material. The plates correspond to elements rising from the bedrock which are smaller here than in the southern part of the shelter. As mentioned earlier, the archaeological level in the north sector concerns the occupation of the front of the shelter, with block K lying on a ledge marked by a rise in the bedrock.

\section{Cultural attribution}

The north sector and the purple layer yielded a considerable quantity of objects during evaluation operations in 1994, clearly attributable to the early Aurignacian. The limited excavated surface under the block yielded little material but is also characteristic of the early Aurignacian, with two "basket-shaped" beads (including one rough out), a reindeer antler rod obtained by fracturing, several retouched blades $(n=4)$, an Aurignacian blade, end scrapers on blades ( $n=3)$ and an angle burin (cf. fig. 2). Even though we cannot affirm a strict correspondence between the north and south sectors, these two complexes cannot be culturally distinguished.

\section{Dating}

A bone fragment adhering to the decorated surface of block $\mathrm{K}$ and five others from the underlying archaeological layer were dated by the Oxford Radiocarbon Accelerator Unit, after treatment by molecular ultrafiltration (White et al. 2012). These dates are perfectly internally coherent and provide an average non-calibrated age of 32,400 BP, with very tight error margins. The ${ }^{14} \mathrm{C}$ dates from the north and south sectors of the site are statistically identical, including those from the south sector carried out by the Gifsur-Yvette laboratory (tab. 1). 
Table $1-{ }^{14} \mathrm{C}$ dates for the northern and southern sectors of the Castanet shelter (after White et al. 2011).

\begin{tabular}{|c|c|c|c|c|c|}
\hline $0 \times A$ & Échantillon & Unité Strati. & Espèce & Date & $+\%$ \\
\hline 21558 & Sud G11A 177 & 114 & Renne & 32350 & 450 \\
\hline 21559 & Sud G11A 179 & 114 & Renne & 33250 & 500 \\
\hline 21560 & Sud G11A 180 & 114 & Renne & 32800 & 450 \\
\hline 21561 & Sud G12A 242 & 110 & Os de mammifère (ind.) & 32050 & 450 \\
\hline 21562 & Sud G12A 244 & 110 & Renne & 32550 & 450 \\
\hline 21563 & Sud G12C 122 & 110 & Renne & 32600 & 450 \\
\hline 21564 & Sud G12C 129 & 110 & Renne & 32950 & 500 \\
\hline 21566 & Sud G12A 252 & 110 & Herbivore de taille moyenne & 32550 & 600 \\
\hline 21639 & Nord-surface gravée & Purple layer & Os de mammifère (ind.) & 32900 & 500 \\
\hline 21640 & Nord SS6C- 80 & Purple layer & Os de mammifère (ind.) & 31900 & 450 \\
\hline $21641^{*}$ & Nord SS6C-25 & Purple layer & Os de mammifere (ind.) & 31950 & 450 \\
\hline $21642^{*}$ & Nord SS6C-25 & Purple layer & Os de mammifère (ind.) & 32500 & 450 \\
\hline 21643 & Nord RR6B-1 & Purple layer & Os de mammifère (ind.) & 32200 & 450 \\
\hline 21644 & Nord RR5C-8 & Purple layer & Os de mammifere (ind.) & 32350 & 450 \\
\hline 21645 & Nord J13C- 22 & Purple layer & Os de mammifère (ind.) & 32000 & 450 \\
\hline Gif & Echantillon & Unité Strati. & Espèce & Date & $4 /-$ \\
\hline 97313 & Sud I11 A 243 & 131 & Os de mammifère (ind.) & 32750 & 460 \\
\hline 97312 & Sud 111 A 290 & 131 & Os de mammifère (ind.) & 32460 & 420 \\
\hline 99166 & Sud H12D 131 & 131 & Os de mammifère (ind.) & 34320 & 520 \\
\hline 99165 & Sud 112 D 158 & 114 & Os de mammifère (ind.) & 31430 & 390 \\
\hline 99179 & Sud H12D 138 & 122 & Os de mammifère (ind.) & 32310 & 520 \\
\hline 99180 & Sud H12 D 156 & 122 & Os de mammifère (ind.) & 32950 & 520 \\
\hline 97330 & Sud K13 A 1416 & 101 & Os de mammifère brùlé & 24950 & 240 \\
\hline
\end{tabular}

\section{T. Higham, H. Valladas and N. Tisnerat.}

With Bayesian modeling, OxCal 4.1 (Bronk Ramsey 2001, 2009a, 2009b) and INTCAL09 (Reimer et al. 2009), which generates calibration curves; it was possible to evaluate the chronology of the north sector. These analyses show that the earliest occupation of the Castanet site dates between 37,190-36,630 BP (68.2 \% prob.) and 37,880-36,530 BP (95.4 $\%$ prob.). The end of this occupation occurs between $36,760-36,330$ BP (68.2 \% prob.) and $37,000-35,770$ BP ( $95.4 \%$ prob.). These results thus indicate a relatively brief period of activity, between $36,940-36,510 \mathrm{BP}$ ( $68.2 \%$ prob.).

41 We can consider that these radiometric data provide a rather accurate estimation of the age of the purple layer. The absence of deposits between the Aurignacian level and the lower surface of block K implies that the most likely hypothesis is that the block fell onto an active or recently abandoned occupation level.

Although we are not in a position to determine the time lapse between the occupation of the archaeological level and the collapse of the block which sealed this level, we currently consider that these dates are the terminus ante quem for the ornamentation of the block. It is important to point out that an age of $24,950 \pm 240$ was obtained for a burnt bone fragment situated just above the collapsed ceiling block, indicating limited Gravettian presence after the destruction of the rock shelter. In order to confirm this hypothesis, an OSL feasibility study is being carried out under block $\mathrm{K}$ to date the collapse of the ceiling.

The decorated surface of block $\mathrm{K}$ is thus relatively old, even for Aurignacian rock art, for which most of the radiometric data come from Chauvet cave. The comparison of the dates from Castanet with those from Chauvet (White et al. 2012) suggests that the 
Castanet art is slightly earlier, if we accept the hypothesis that the art is synchronous with the occupation level of the site.

\section{The analysis of the archaeological material as a contextualization element of the block}

\section{The archaeological material in physical relation to the decorated block}

The main aim of the study of the archaeological objects is to provide precious elements related to the context of the decorated block. Indeed, it is possible to affirm that the archaeological material underwent a substantial shock which, in all probability, corresponds to the collapse of the block. The study of the archaeological material also provides several taphonomic arguments pointing to the in situ collapse of the block with very little post-depositional displacement, both for the block and the remains (Chiotti \&t Cretin 2007; Cretin \& Chiotti 2008). We can thus advance the following arguments:

- the breakage rate of the lithic material is very high. This fracturing was directly observed in the field by the presence of pieces broken on site (fig. 7). Out of 26 refitted pieces, 17 are fractured. Some are just fractured whereas others present intense crushing marks and several of them were even stuck back together by ulterior concretions. Fragmentation is also visible in sieve remains which present a majority of small shards which are morphologically different from the usual debitage waste (cf. fig. 7).

- lithic waste products are so fractured that no technological reading is possible (not even the orientation of the piece). The proportion of debris is very high (17\% as opposed to $9 \%$ in the south sector):

- similar observations have been made on bone remains (fauna and industry), and it was not possible to extract pieces visible at the excavation due to intense fragmentation. However, multiple factors are responsible for the fracturing of this material (anthropic, postdepositional) and there is not necessarily a strict parallel with the lithic remains. 
Figure 7 - Stone industry beneath the block $K$ showing breakage caused by the collapse of the shelter. a: flake broken in situ; $b$ : flake broken in situ and cemented by concretion; c: retouched broken blade under block K; d: SS5C-36 sieved material, sorted by dimension category, almost exclusively composed of crushed fragments.

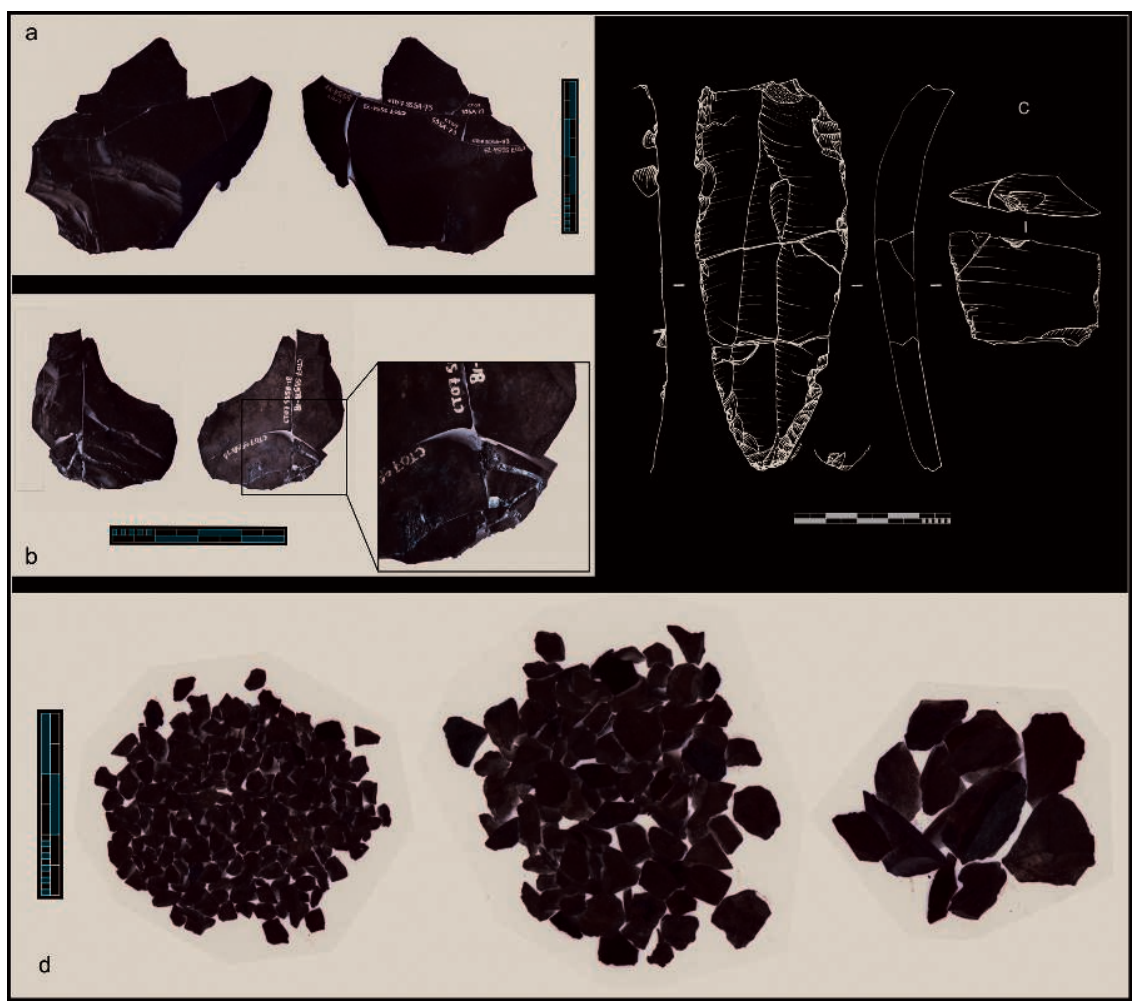

C. Cretin and L. Chiotti.

Lastly, spatial restitution techniques elaborated by M. Sisk in collaboration with A. Clark, allowed us to open the debate on the interrelations between the bedrock, the archaeological layer, the crushed lithic remains and the blocks. At the time being, our observation window is still too limited $\left(1.36 \mathrm{~m}^{2}\right.$ excavated for a volume of less than 900 $\mathrm{cm}^{3}$ ), but we hope to be able to observe crushing phenomena on hard elements (lithic remains and bedrock), and absorption and expulsion phenomena of more flexible elements (archaeological level).

\section{Geological and geomorphological contextualization}

An attempt at characterizing the different limestone microfacies was carried out in order to reposition block $\mathrm{K}$ in its original context in the limestone, as well as a geomorphological study of the valley in order to understand rockshelter formation and functioning.

\section{Geomorphological context}

The massif in which the shelters are located corresponds to the upper period of the Coniacian limestone (C4b in Guillot et al. 1979; Capdeville et Rigaud 1987 - c3Ez in Platel et al. 1999; Karnay et al. 1999). The documented facies have many points in common with the sections described nearby (namely La Roque Saint-Christophe, Platel et al. 
1999). This succession places the limestone in which the rockshelter formed at the limit between the Middle and the Upper Coniacian.

At many places in the valley, porch structures have not been preserved. Only the abrupt cliff subsists and it is often difficult to distinguish the different lithofacies. Moreover, troglodytic structures have largely contributed to the disappearance of identifiable features on natural rock walls. It is important to take this into account during the study of the natural evolution of the vault but it is also particularly significant for the evaluation of the archaeological potential of such sectors, which may have been very damaged (Gardère et al. 2008).

\section{Characterization of the cliff lithofacies}

The observations and stratigraphic recordings of the cliff macro-facies on both the right and the left bank led to the identification of four lithofacies in this Coniacian limestone (A, B, C and D) which elucidate the history of the formation of the rockshelter lines. These lithofacies are as follows from the bottom to the top of the cliff:

- facies A: tender, very bioturbated limestone;

- facies B: made up of two strata with clear limits presenting regular metric undulations. The lower stratum attains 40 to $50 \mathrm{~cm}$ and the upper formation 35 to $40 \mathrm{~cm}$;

- facies C: more or less bioturbated complex organized in oblique stratifications visible over about $60 \mathrm{~cm}$;

- facies D: well crystallized limestone with no visible sedimentary structure overlying the three other facies (only several horizontal stratification joints are visible).

\section{Formation of the rockshelter line}

The formation of the rock shelters results from the differential degradation of the rock depending on the intrinsic vulnerability of the lithofacies considered. In this way, the very bioturbated facies $\mathrm{A}$ is rapidly degraded by meteorological agents. Rock shelters are hollowed out in this vulnerable horizon. Facies B, the initial component of the rockshelter vault, is also susceptible to congelifraction. Good limestone cohesion ensures the detachment of large blocks, whereas the stratification joints delimit the upper-side break-off point. A combination of these two factors results in facies B being broken up into large plane and tabular slabs. Facies $C$ is subject to dissolution because of its heterogeneity. Facies D is the most stable and only breaks up with gravitational forces into blocks with no characteristic shapes.

51 As well as the first horizontal step in the formation of a line of rock shelters - through limestone talus creep of the most fragile facies - there is also the vertical approach induced by joints, faults or cracks in the limestone massif. Dissolution features are thus present all along the cliff. Directly below the breaks, porch height can be greatly increased due to the weakening of the vault which is destroyed faster than in zones with no faults (bell-shaped structures).

\section{A particular case: the sector of the Peyrony section}

The section brings to light staged structuring (fig. 8). At the base, the main archaeological level (the purple layer) is horizontal and lies directly on the bedrock. A first episode of porch destruction provoked the collapse of slabs issued from facies B 
onto the archaeological material. It is at this stage that block $\mathrm{K}$ became detached from the limestone massif. Its size, position in the section and the marks left by it in the sediment indicate that it was not moved. The horizontal nature of the underlying layer and the high rate of crushed lithic remains rule out any possibility of sliding. Block $\mathrm{K}$ fell directly from its initial position in the vault. After this first phase of disintegration of the sector, the dynamic of the infilling changes and a strong tilt to the west develops. Sedimentary texture also varies; the blocks are wrapped in a clayey matrix, evoking formations that slid from higher topographies. Probing evidence of supply from a currently collapsed swallow hole has been brought to light.

Figure 8 - Evolution of the Castanet shelter and formation of the geoarchaeological deposits. Photo captions from left to right: $E=$ scree, $M=$ limestone massif, $C=$ Castanet south; Peyrony section after extraction of block $K$, note the presence of the continuity of block $K$ in the section; formation of scree after ceiling collapse; interstitial filling in of scree with carbonated formations.

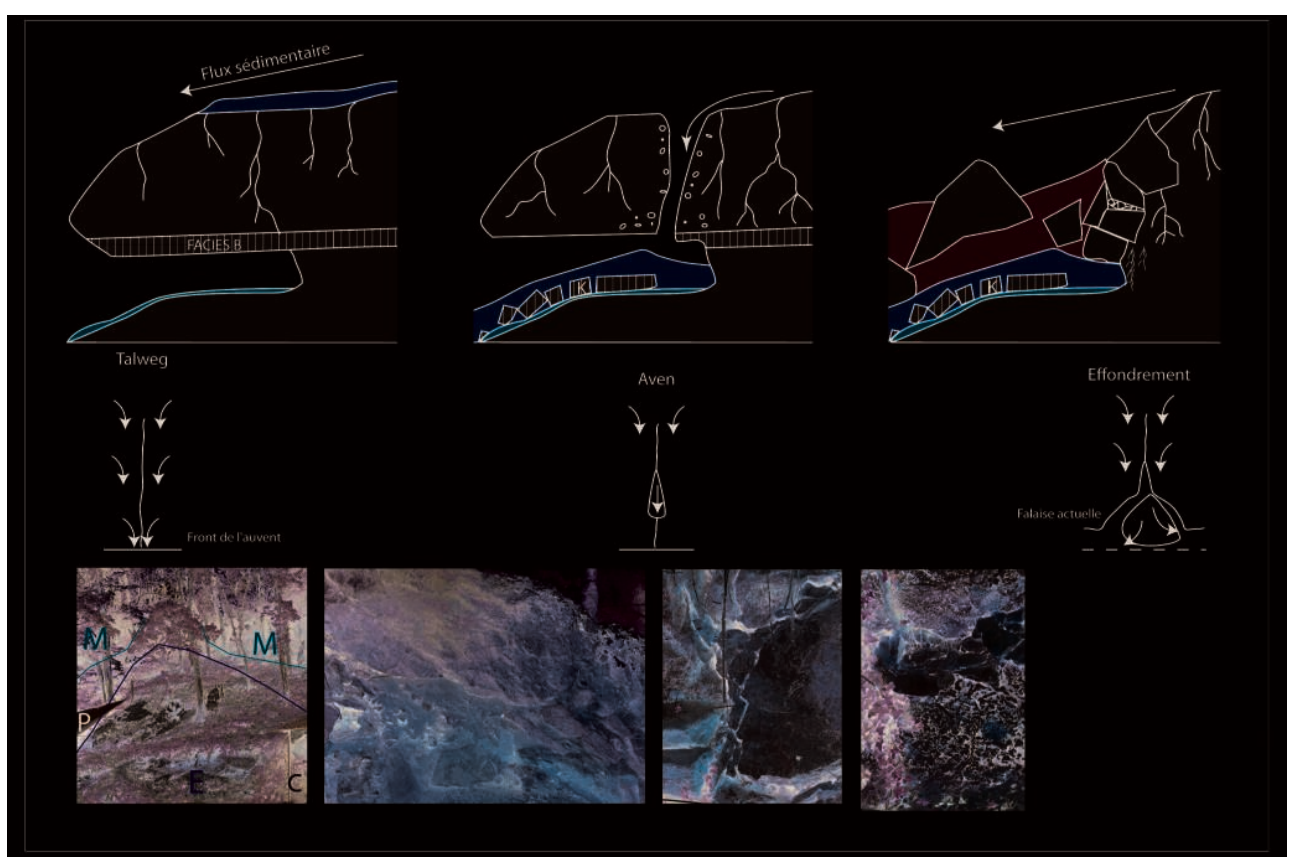

Ph. Gardère.

The evolution of the Peyrony section sector brings to light the different mechanisms likely to have affected the cavities of the valley. During human occupation, rockshelter morphology varied according to the previously described modalities. The collapse of the later elements from the porch marks the summit of the archaeological levels. The destabilization of the massif due to rock collapse is accentuated by the dissolution of fractured zones. Very large blocks can then slide or cave in (for example south of Abri Labattut on the western slope or in the sector of the Peyrony section), rendering the rock wall very steep.

\section{5 - Conclusion}

The work presented here brings to light site evolution processes from the formation of the rockshelter to its total concealment by fallen blocks. Inside the shelter, it was 
possible to identify blocks collapsed from the ceiling and the role of human occupations in this process.

Collapsed blocks from the decorated ceiling came into direct contact with the archaeological levels, as shown by the lithic remains, which allow us to envisage a terminus ante quem for the ceiling engravings. In order to grasp the relative chronology of these events more accurately, a feasibility study for OSL dates is underway. This will yield a date for the fallen block and the scree overlay.

As for the exceptional parietal art discovery, it is a fragment of the decorated ceiling which protected the Aurignacian occupation.

It thus appears to be indispensable to continue archaeological excavations at the site. Between the north and south sectors, there is over $7 \mathrm{~m}$ of non-excavated scree which will enable us to widen our observation window and possibly to discover other decorated ceiling elements. Indeed, we know that in the Peyrony section, in the continuity of block K, other block elements are related to this collapsed ceiling.

Complementary research orientations will aim to:

- gain a better understanding of the occupation level, in the aim of improving the representativeness of the excavated surface, to detect different activity zones and consequently to address the palaeoethnological dimension of the site;

- to document the geomorphological context and to locate the extension of the ceiling, which may be decorated;

- to establish a closer link between the two preceding elements in order to gain a better understanding of the social context of human activities carried out at this exceptional site.

This ultimate objective also requires more extensive research on the valley as a whole, on other rock art elements and their contexts of. Indeed, work on archives and previously discovered elements (R. White \& R. Bourrillon) confirms that there are rock art representations on the shelter walls and blocks on the ground, but also that the Castanet and Blanchard sites present a number of graphic and technical similarities and may be two parts of the same Aurignacian occupation.

Since 1994 this research has been supported by a number of institutions to whom we extend our thanks: the United States National Science Foundation, la Direction régional des affaires culturelles d'Aquitaine (DRAC-Aquitaine), the Partner University Fund (PUF), the Andrew Mellon Foundation, the L.S.B. Leakey Foundation, the Reed Foundation, the Rock Foundation, the Fine Foundation, l'UMI 3199-CNRS-NYU (Center for International Research in the Humanities and Social Sciences), the Institute for Ice Age Studies, the Theodore Dubin Foundation, le Service archéologique départemental (SAD) de la Dordogne, New York University, Fondation Fyssen and the Fulbright Foundation.

The authors also wish to thank the following people for their help, advice and support: the Castanet and Castanet-Daumas families, Hélène Talenton, Jean-Pierre Lagarde, Baptiste and Edith Burg, John Yellen, Dany Barraud, Nathalie Fourment, Jean-Jacques Cleyet-Merle, Serge Maury, Jean-Michel Geneste, Emilienne Baneth-Nouailhetas, Christophe Goddard, Edward Berenson, Mike Habermann, Lois Dubin, Jean-Christophe Portais, Philippe Jugie, Jacqueline Angot-Westin, Eric Capdeville, Christophe Vigerie, Jean and Annie Labeille, Jean-Paul Blémont, Philippe Mourneau. 


\section{BIBLIOGRAPHY}

AZÉMA M., GÉLY B., BOURRILLON R., LHOMME D. submitted - La grotte ornée paléolithique de Baume-Latrone (France, Gard) : la 3D remonte le temps. In : J. Clottes et C. González Morales (Éd.), L'Art pléistocène dans le monde, symposium L'Art Pléistocène en Europe. Actes du Congrès International IFRAO, (6-11 septembre 2010). Ariège.

BEAUNE (de) S. 1993 - Approche expérimentale de techniques paléolithiques de façonnage de roches peu aptes à la taille. Paleo, 5, p. 155-177.

BON F. 2002 - L'Aurignacien entre Mer et Océan. Réflexion sur l'unité des phases anciennes de l'Aurignacien dans le Sud de la France. Joué-Lès-Tours : Société Préhistorique Française, mémoire XIX, $253 \mathrm{p}$.

BOURRILLON R. 2007 - Analyses et relevés préliminaires. In : R. White (Ed.), Abri Castanet, secteurs Sud et Nord (Commune de Sergeac, Dordogne). Rapport de Fouille Programmée, années 2006-2008. Bordeaux : Service Régional de l'Archéologie, Ministère de la Culture, p. 109-120.

BOURRILLON R. 2009a - Les représentations humaines sexuées dans l'art du Paléolithique supérieur européen : diversité, réminiscences et permanences. Toulouse : Université de Toulouse II le Mirail, 2009, 2 t., 552 p., ill, Thèse de $3^{\mathrm{e}}$ cycle : Archéologie : Toulouse II.

BOURRILLON R. 2009b - Les figures humaines segmentées et isolées : pérennité et ruptures. In: D. Seglie, M. Otte, L. Oosterbeek, L. Remacle (Eds), Prehistoric art. Signs, Symbols, Myth, Ideology. Actes $\mathrm{du} 15^{\mathrm{e}}$ Congrès UISPP, Lisbonne (septembre 2006). Oxford : BAR, 27, p. 21-28.

BOURRILLON R., WHITE R. 2007 - Le bloc K de Castanet dans l'Aurignacien d'Aquitaine In : R. White (Ed.), Abri Castanet, secteurs Sud et Nord (Commune de Sergeac, Dordogne). Rapport de Fouille Programmée, années 2006-2008. Bordeaux : Service Régional de l'Archéologie, Ministère de la Culture, p. 121-124.

BOURDIER C., FUENTES O., HAMON G., PINÇON G. 2008 - Technologies 3D appliquées à la sculpture pariétale magdalénienne. In : O. Buchsenchutz (Éd.), Images et relevés archéologiques, de la preuve à la démonstration. Actes du $132^{\mathrm{e}}$ Congrès national des Sociétés Savantes Historiques et Scientifiques (2007). Arles, CDRom.

BRONK RAMSEY C. 2001 - Development of the radiocarbon calibration program OxCal. Radiocarbon, 43, n²A, p. 355-363.

BRONK RAMSEY C. 2009a - Bayesian analysis of radiocarbon dates. Radiocarbon, 51, nº1, p. 337-360.

BRONK RAMSEY C. 2009b - Dealing with outliers and offsets in radiocarbon dating. Radiocarbon, $51, \mathrm{n}^{\circ} 3$, p. 1023-1045.

CAPDEVILLE J.-P., RIGAUD J.-P. 1987 - Carte géologique 1/50 000, Notice explicative, feuille Sarlat - La Canéda. Orléans : 808, BRGM.

CHIOTTI L. 2005 - Les Industries lithiques aurignaciennes de l'abri Pataud, Dordogne, France : les fouilles de Hallam L. Movius Jr., Oxford, BAR International Series, Archaeopress, 839 p.

CHIOTTI L., CRETIN C. 2007 - Étude du matériel lithique de l'abri Castanet (secteur sud et coupe Peyrony) Campagnes 2005-2007. In : R. White (Éd.), Abri Castanet, Nouveau Secteur. Rapport de Fouille Programmée, année 2007. Bordeaux : Service Régional de l'Archéologie, Ministère de la Culture, p. 132-155. 
CRETIN C., CHIOTTI L. 2008 - Le matériel lithique de l'abri Castanet. Bilan des campagnes 2005-2008. In : R. White (Ed.), Abri Castanet, Nouveau Secteur. Rapport de Fouille Programmée, années 2006-2008. Bordeaux : Service Régional de l'Archéologie, Ministère de la Culture, p. 144-195.

DELLUC B. et G. 1978 - Les manifestations graphiques aurignaciennes sur support rocheux des environs des Eyzies (Dordogne). Paris : Gallia Préhistoire, CNRS, 21, n¹ et 2, p. 213-438, 96 fig.

DELPORTE H. 1984 - Le grand abri de La Ferrassie. Fouilles 1968-1973. Publications de l'Université de Provence : Études Quaternaires, mémoire n 7277 p.

CHAMPAGNE F., ESPITALIÉ R. 1981 - Le Piage, site préhistorique du Lot. Paris : Mémoires de la Société Préhistorique Française, XV, 208 p.

FRITZ C., TOSELLO G. 2007 - The Hidden Meaning of Forms: Methods of Recording Paleolithic Parietal Art. New-York : Journal of Archaeological Method and Theory, 14, n¹, p. 48-80.

FRITZ C., TOSELLO G., PÉRAZIO G., PÉRAL J., GUICHARD L. 2010 - Technologie 3D et relevé d'art

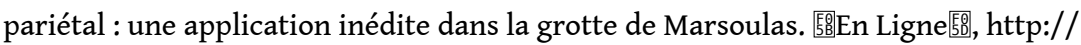
www.revue.inventaire.culture.gouv.fr/insitu/insitu/, Ministère de la Culture.

GARDÈRE P., WHITE R., SISK M., CLARK A. 2008 - Un travail en cours : les abris Castanet et Blanchard dans leur contexte géomorphologique, géokarstique et paléotopographique. In : R. White (Ed.), Abri Castanet, Nouveau Secteur. Rapport de Fouille Programmée, année 2008. Bordeaux : Service Régional de l'Archéologie, Ministère de la Culture, p. 92-143.

GUILLOT P. L., FEYS R., LEFAVRAIS-RAYMOND A., PLATEL J. P., LEFAVRAIS-HENRY M., BASSOULET J. P., CONTINI D., GOURDON-PLATEL N., QUARANTOTTI G., VANACKER J. C., TOILLIEZ L., PARFENOFF A. 1979 - Carte géologique 1/50 000, Notice explicative, feuille de Terrasson, 784. Orléans : BRGM.

KARNAY G., avec la collaboration de AUJOULAT N., KONIK S., MAUROUX B., PLUCHERY E., TURQ A. 1999 - Carte géologique 1/50 000, feuille Le Bugue (807), Notice explicative. Orléans : BRGM, 91 p.

LORBLANCHET M. 1995 - Les grottes ornées de la Préhistoire - Nouveaux regards. Paris : Errance, $288 \mathrm{p}$.

MENSAN R. 2007 - Poursuite de la fouille de l'abri Castanet. In : R. White (Ed.), Abri Castanet, Nouveau Secteur. Rapport de Fouille Programmée, année 2007. Bordeaux : Service Régional de l'Archéologie, Ministère de la Culture, p. 60-68.

MENSAN R., SISK M. 2008 - Poursuite de la fouille de l'abri Castanet : 2007 et 2008, In : R. White (Ed.), Abri Castanet, Nouveau Secteur. Rapport de Fouille Programmée, année 2006-2008. Bordeaux : Service Régional de l'Archéologie, Ministère de la Culture, p. 64-77.

MOUTHON A., JOFFROY R. 1958 - Le gisement aurignacien des Rois à Mouthiers (Charente). Paris : Gallia-Préhistoire, IX ${ }^{\mathrm{ème}}$ supplément, CNRS, $140 \mathrm{p}$.

PELEGRIN J., WHITE R. 1998 - Abri Castanet : Rapport de Fouille Programmée, années 1996-1998. Bordeaux : Service Régional de l'Archéologie, Ministère de la Culture.

PEYRONY D. 1935 - Le gisement Castanet, Vallon de Castelmerle, commune de Sergeac (Dordogne), Aurignacien I et II. Bulletin de la Société Préhistorique Française, 32, p. 418-443.

PINÇON G. 2004 - Méthodes de relevé appliquées à l'étude de l'art pariétal sculpté magdalénien du Roc-aux-Sorciers (Angles-sur-l'Anglin, France). Bulletin de l'Association des Archéologues de Poitou-Charentes, 33, p. 41-58. 
PLATEL J. P., avec la collaboration de FAUGERAS P., MAUROUX B., SPENCER C., CHARNET F, CÉLERIER G., HARIELLE B., JACQUEMENT P. 1999 - Carte géologique 1/50 000, feuille Thenon (783), Notice explicative. Orléans : BRGM, 129 p.

REIMER P.J., BAILLIE M.G.L., BARD E., BAYLISS A., BECK J.W., BLACKWELL P.G., BRONK RAMSEY C., BUCK C.E., BURR G., EDWARDS R.L., FRIEDRICH M., GROOTES P.M., GUILDERSON T.P., HAJDAS I., HEATON T.J., HOGG A.G., HUGHEN K.A., KAISER K.F., KROMER B., MCCORMAC F.G., MANNING S.W., REIMER R.W., RICHARDS D.A., SOUTHON J.R., TALAMO S., TURNEY C.S.M., VAN DER PLICHT J., WEYHENMEYER C.E. 2009 - Intcal09 and Marine09 radiocarbon age calibration curves, 0-50,000 years cal BP. Radiocarbon, 51, nº, p. 1111-1150.

RIGAUD J. Ph. 1993 - L'Aurignacien dans le Sud-Ouest de la France, bilan et perspectives. In : L. Banesz et J. Kozlowski (Ed.), Aurignacien en Europe et au Proche-Orient. Actes du colloque organisé par la Commission VIII e de l'UISPP à Bratislava (1-7 septembre1991). Nitra-Bratislava : Institut Archéologique de l'Académie Slovaque des Sciences, p. 181-186 (vol. 2).

SANOIT (de) J., CHAMBELLAN D., PLASSARD F. 2005 - Caractérisation in situ du pigment noir de quelques œuvres pariétales de la Grotte de Rouffignac à l'aide d'un système portable d'analyse par fluorescence X (XRF). ArchéoSciences, 29, p. 61-68.

SISK M. L. 2010 - Three-Dimensional Gigapan Views of Archaeological Sites and Artifacts: Examples from the Paleolithic of Southwest France. In: Proceedings of the Fine International

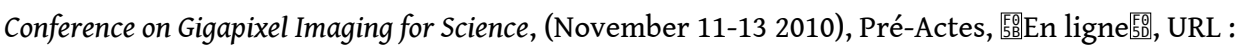
http://gigapixelscience.gigapan.org/papers-2?offset=30.

SONNEVILLE-BORDES (de) D. 1960 - Le Paléolithique supérieur en Périgord. Bordeaux : Delmas, $558 \mathrm{p}$.

TARTAR É. 2007 - L'industrie en os et en bois de renne. In : White R. (Ed), Abri Castanet, Nouveau Secteur. Rapport de Fouille Programmée, année 2007. Bordeaux : Service Régional de l'Archéologie, Ministère de la Culture, p. 156-164.

TARTAR É. 2009 - De l'Os à l'Outil : Caractérisation technique, économique et sociale de l'utilisation de l'os à l'Aurignacien ancien. Étude de trois sites : l'Abri Castanet (secteurs nord et surd), Brassempouy (Grotte des Hyènes et abri Dubalen) et Gatzarria. Paris : Université de Paris I-Panthéon-Sorbonne, 2009, 2 t., 300 p. Thèse de $3^{\mathrm{e}}$ cycle : Archéologie : Paris I-Panthéon-Sorbonne.

TEXIER J. P. 2009 - Histoire géologique de sites préhistoriques classiques du Périgord : une vision actualisée : La Micoque, La grotte Vaufrey, Le Pech de l'Azé I et II, La Ferrassie, L'abri Castanet, Le Flageolet, Laugerie-Haute. Paris : CTHS, $193 \mathrm{p}$.

TYMULA S. 1999 - L'art du Roc-de-Sers (Charente) dans son contexte solutréen. Paris : Université de Paris I (Panthéon-Sorbonne), 1999. 2 t., 845 p., ill. Thèse ND : Sc. : Paris I.

WHITE R. 2005 - Abri Castanet, Nouveau Secteur. Rapport de Fouille Programmée, année 2005. Bordeaux : Service Régional de l'Archéologie, Ministère de la Culture, $110 \mathrm{p}$.

WHITE R. 2006 - Abri Castanet, Nouveau Secteur. Rapport de Fouille Programmée, année 2006. Bordeaux : Service Régional de l'Archéologie, Ministère de la Culture, 184 p.

WHITE R. 2007 a - Abri Castanet, Nouveau Secteur. Rapport de Fouille Programmée, année 2007. Bordeaux : Service Régional de l'Archéologie, Ministère de la Culture, 186 p.

WHITE R. 2007 b - Morphologie de l'abri et étude du réseau karstique sous Castel-Merle. In : White R. (Éd.), Abri Castanet, Nouveau Secteur. Rapport de Fouille Programmée, année 2007. Bordeaux : Service Régional de l'Archéologie, Ministère de la Culture, p. 69-73. 
WHITE R. 2007 c - Sergeac. L'abri Castanet. Bilan scientifique de la région Aquitaine, 2005. Bordeaux : Service régional de l'Archéologie, Drac Aquitaine, Ministère de la Culture et de la Communication, p. 52.

WHITE R. 2008 a - Abri Castanet, Nouveau Secteur. Rapport de Fouille Programmée, années 2006- 2008. Bordeaux : Service Régional de l'Archéologie, Ministère de la Culture, 292 p.

WHITE R. 2008 b - Objets de parure et objets osseux décorés à l'abri Castanet, Secteurs sud et nord 2005 à 2008. In : White R. (Éd.), Abri Castanet, Nouveau Secteur. Rapport de Fouille Programmée, années 2006-2008. Bordeaux : Service Régional de l'Archéologie, Ministère de la Culture, p. 244-274.

WHITE R. 2008 c - Sergeac. Abri Castanet. Bilan scientifique de la région Aquitaine, 2006. Bordeaux : Service régional de l'Archéologie, Drac Aquitaine, Ministère de la Culture et de la Communication, p. 42-44.

WHITE R. 2009 a - Abri Castanet, Nouveau Secteur. Rapport de Fouille Programmée, année 2009. Bordeaux : Service Régional de l'Archéologie, Ministère de la Culture, 222 p.

WHITE R. 2009 b - Sergeac. Abri Castanet. Bilan scientifique de la région Aquitaine, 2007. Bordeaux : Service régional de l'Archéologie, Drac Aquitaine, Ministère de la Culture et de la Communication, p. 60-61.

WHITE R., CRETIN C., CHIOTTI L., BOURRILLON R., SISK M., GARDERE Ph. 2007 - Fragment de la voûte gravée et colorée de l'abri Castanet (Secteur nord). In : White R. (Éd.), Abri Castanet, Nouveau Secteur. Rapport de Fouille Programmée, année 2007. Bordeaux : Service Régional de l'Archéologie, Ministère de la Culture, p. 74-131.

WHITE R., BOURRILLON R. 2008 - Avancement étude du bloc K. In : White R. (Ed.), Abri Castanet, Nouveau Secteur. Rapport de Fouille Programmée, années 2006-2008. Bordeaux : Service Régional de l'Archéologie, Ministère de la Culture, p. 81-91.

WHITE R., HIGHAM T. 2008 - Bilan des datations C14 pour le Secteur sud et nord. In : White R. (Ed.), Abri Castanet, Nouveau Secteur. Rapport de Fouille Programmée, années 2006-2008. Bordeaux : Service Régional de l'Archéologie, Ministère de la Culture, p. 78-80.

WHITE R., MENSAN R., SISK M., CLARK A. 2010 - Sergeac. Abri Castanet. Bilan scientifique de la région Aquitaine, 2008. Bordeaux : Service régional de l'Archéologie, Drac Aquitaine, Ministère de la Culture et de la Communication, p. 52-55.

WHITE R., MENSAN R., BOURRILLON R., CRETIN C., HIGHAM T., CLARK A., SISK M., TARTAR E., GARDERE P., PELEGRIN J., VALLADAS H., TISNERAT-LABORDE N., SANOIT (de) J., CHAMBELLAN D., CHIOTTI L. 2012 - Context and dating of a newly discovered Aurignacian "vulvar" representation from Abri Castanet, France. Proceedings of the National Academy of Science.

\section{NOTES}

1. In relation to this, see: Mouthon, Joffroy 1958; Champagne, Espitalié 1981; Delporte 1984; Rigaud 1993; Bon 2002; Chiotti 2005.

2. It is for this reason that the numerical order does not follow the chronology of events as K1 and $\mathrm{K} 2$ were inverted, and $\mathrm{K} 2$ was the first block removed. Moreover, the block fragments bearing a decorated surface were not numbered. They were designated in the following way: "fragment of intermediary block 3-4" for an element removed between blocks 3 and 4 . There are in fact four intermediary blocks (2-1, 3-4, 4-5 and 4-5 bis). 
3. The Gigapan is a robotic device used for taking a series of partially overlapping images (up to several hundred) and to restitute them as a single high resolution image ( $0.5-2$ gigapixels). Then software developed by the GigaPan team creates a photomosaic based on all the images. GigaPan software modifies the definition of the image depending on the zoom level, using rapid image navigation for images of more than one gigabyte. This tool provides a unique opportunity to document the whole of the surface of block $\mathrm{K}$ in a single image (Sisk 2010). As well as helping with the recording, the GigaPan images make it possible to visualize the block in three dimensions (http://www.gigapan.org/viewProfile.php?userid=4885). The most recent version of this device was kindly lent to us by Carnegie-Mellon University.

4. The application of this technology to rock art has developed significantly these past years. For example, work in the Roc-aux-Sorciers and La Chaire-à-Calvin rock shelters (Pinçon 2004; Bourdier et al. 2008), in the caves of Baume Latrone (Azéma et al. soumis) and Marsoulas (Fritz et al. 2010).

5. The scanner Konica Minolta VI 910 was kindly lent to us by the Laboratoire de Recherche TRACES UMR 5608, Toulouse.

6. "Reserve relief: this procedure of direct shaping consists in working the background all around reserved features or patterns in order to obtain relief. The background is worked by an outline with a recticurvilinear section with a modeled edge and a sunken edge, with a depth which can reach about $1 \mathrm{~cm}$. This reserve relief confers a flat or semi-ledge aspect and can have a flat base or a bowl-shaped base" (Tymula 1999 - p. 232).

\section{ABSTRACTS}

In this paper we report on the discovery in 2007 in archaeological context, of part of the engraved and ocher-stained undersurface of the rockshelter ceiling from Abri Castanet, Commune de Sergeac, Dordogne. The engraved/painted undersurface of the massive roofcollapse block, weighing more than a ton, was in direct contact with the surface of the early Aurignacian archaeological layer onto which it had fallen. A series of six molecular filtration dates on faunal bone from the rock surface are internally coherent and yield a mean age estimate of 32,400 radiocarbon years BP. The clearest engraving observable on the newly discovered ceiling fragment fits morphologically into the category of vulvar images, many examples of which were recovered during excavations at the beginning of the 20th century at Abri Castanet and the adjacent site of Abri Blanchard. This new discovery from Castanet provides an age estimate for those earlier finds, all of which were located within a few meters of the image described here.

\section{INDEX}

Keywords: Abri Castanet, Engraved block, Context, Dating, Aurignacian 


\section{AUTHORS}

\section{ROMAIN MENSAN}

Université Toulouse II-le Mirail, Maison de la Recherche, Laboratoire TRACES UMR 5608, 5, allées Antonio Machado, 31058 Toulouse Cedex 9, France - mensrom@gmail.com

\section{RAPHAËLLE BOURRILLON}

Université Toulouse II-le Mirail, Maison de la Recherche, Laboratoire TRACES UMR 5608 - CREAP, 5, allées Antonio Machado, 31058 Toulouse Cedex 9, France ou Center for the Study of Human Origins, New York University, 25 Waverly Place, New York, NY 10003 USA - bourrillon@univtlse2.fr

\section{CATHERINE CRETIN}

Centre National de Préhistoire, Sous-direction de l'Archéologie, Direction générale des Patrimoines, Ministère de la Culture et de la Communication, 38, rue du 26e Régiment d'Infanterie, 24000 Périgueux, France - catherine.cretin@culture.gouv.fr

\section{RANDALL WHITE}

Center for the Study of Human Origins, New York University, 25 Waverly Place, New York, NY 10003 USA - randall.white@nyu.edu

\section{PHILIPPE GARDÈRE}

Institut National de Recherches Archéologiques Préventives (INRAP), Base de Tours, 148, avenue Maginot, 37000 Tours, France - philippe.gardere@numericable.fr

\section{LAURENT CHIOTTI}

Muséum national d'histoire naturelle, Département de Préhistoire, UMR 7194, abri Pataud, 20, rue du Moyen-Âge, 24620 Les Eyzies-de-Tayac, France - lchiotti@mnhn.fr

\section{MATTHEW SISK}

IDPAS, Department of Anthropology, Stony Brook University, Stony Brook, NY 11794, USA mlsisk@gmail.com

\section{AMY CLARK}

School of Anthropology, PoBox 210030, University of Arizona, Tucson AZ 85721 USA aeclark@email.arizona.edu

\section{THOMAS HIGHAM}

Radiocarbon Accelerator Unit, Research Laboratory for Archaeology \& the History of Art, Dyson Perrins Building, University of Oxford, South Parks Rd, Oxford, OX1 3QY, UK thomas.higham@rlaha.ox.ac.uk

\section{ÉLISE TARTAR}

UMR 7041 ArScAn, Ethnologie préhistorique, Maison de l'Archéologie et de l'Ethnologie, 21, allée de l’Université - 92023 Nanterre cedex, France - elise.tartar@gmail.com 